\title{
35. COMPARISON OF MULTICHANNEL SEISMIC REFLECTION DATA TO ASYNTHETIC SEISMOGRAM AND LITHOLOGY OF SITE 786 ${ }^{1}$
}

\author{
Michael S. Marlow, ${ }^{2}$ Eric L. Geist, ${ }^{2}$ Michael A. Hobart, ${ }^{3}$ Gregory F. Moore, ${ }^{4}$ and Brian Taylor ${ }^{4}$
}

\begin{abstract}
A synthetic seismogram was constructed by using velocity and density logs collected at Ocean Drilling Program Site 786 in the Izu-Bonin forearc. Good agreement was found between the synthetic reflections and most of the observed reflections on a 96-channel seismic reflection profile across the forearc. Short and discontinuous deep reflections occur on the seismic reflection record that correspond to events from within the volcanic basement rocks below the site. These deep reflections correspond to variations in velocity and density observed on the downhole logs that result from different rock types and structures within the volcanic basement rocks. A prominent and laterally continuous basement reflection corresponds to lithologic boundaries between a basalt flow and surrounding breccia layers.
\end{abstract}

\section{INTRODUCTION}

In preparation for Ocean Drilling Program (ODP) Leg 125, a series of geophysical transects were run in the Izu-Bonin forearc, using the Fred H. Moore. Descriptions of these data, including multichannel seismic (MCS) reflection sections, are given by Horine et al. (1990). The seismic reflection data were collected by using a 3065 -in. ${ }^{3}$ air-gun array and a 96-channel streamer. A 12.5-km-long segment of one of the MCS lines (Line 5, Fig. 1) was reprocessed and is shown in Figure 2. Standard processing techniques (listed in Table 1) were applied to the line except for an $\mathrm{f}-\mathrm{k}$ migration of the data. No automatic gain control was applied to these data.

\section{SYNTHETIC SEISMOGRAM}

To create the synthetic seismogram, the velocity and density logs were first edited to remove erroneous values and to eliminate portions where no data were collected. Logs (Fig. 3) were then converted to time by using the time-depth relation calculated from the velocity log. Reflection coefficients were computed from acoustic impedance, accounting for vertical-incidence transmission loss through the section. The synthetic seismogram was then created by convolving the reflection coefficients with a $35-\mathrm{Hz}$ Ricker wavelet and by resampling to $4 \mathrm{~ms}$.

The migrated section was wavelet processed to an approximately zero phase. The $35-\mathrm{Hz}$ Ricker wavelet closely matches the wavelet extracted from the data. Both the synthetic seismogram and the migrated section were then depth-converted using smoothed velocities from the velocity $\log$. Dissimilarities between the synthetic seismogram and the seismic reflection data arise because the synthetic seismogram contains higher frequencies than the seismic reflection data and because the lateral continuity of reflections in the reflection data is less than the Fresnel zone and thus is transitional, whereas in the log data and derived synthetic seismogram the lateral continuity of reflections is well-defined across lithologic boundaries.

'Fryer, P., Pearce, J. A., Stokking, L. B., et al., 1992. Proc. ODP, Sci. Results, 125: College Station, TX (Ocean Drilling Program).

${ }^{2}$ U.S. Geological Survey, 345 Middlefield Rd., Menlo Park, CA 94025, U.S.A.

${ }^{3}$ Lamont-Doherty Geological Observatory, Palisades, NY 10964, U.S.A.

${ }^{4}$ University of Hawaii, 2525 Correa Rd., Honolulu, HI 96822, U.S.A.

\section{COMPARISON OF SYNTHETIC SEISMOGRAM TO SEISMIC REFLECTION RECORD AND DOWNHOLE LITHOLOGY}

Reflections within the sedimentary section correlate well with the synthetic events between about 3130 and $3200 \mathrm{~m}$ (Fig. 2). At $3200 \mathrm{~m}$, a strong and laterally continuous reflection separates overlying sedimentary strata from volcanic basement. This reflection is evident on both the MCS profile and the synthetic traces. This boundary separates the well-stratified, overlying Eocene through Pleistocene sedimentary section, which is characterized by laterally continuous reflections, from the Eocene volcanic basement rocks (Figs. 2 and 4; Fryer, Pearce, Stokking, et al., 1990), which are characterized by one laterally continuous reflection and by many short, discontinuous reflections.

Well-correlated events occur at $3300 \mathrm{~m}$ within the volcanic basement rocks. Both the MCS data and the synthetic-seismogram traces show a strong and laterally continuous intrabasement reflection (Fig. 2). This strong reflection (at $200 \mathrm{mbsf}$ in Fig. 4) corresponds to a basalt layer within two breccia units. Below about $3300 \mathrm{~m}$, correlation between the MCS data and the synthetic-seismogram traces is difficult, probably because reflections deep within the volcanic base-

Table 1. Standard processing techniques.

\begin{tabular}{l}
\hline Processing sequence \\
\hline Edit noisy traces \\
Resample to $4 \mathrm{~ms}$ \\
Sort to 16.67 -m common-midpoint (CMP) bins \\
Trace balance \\
Gain recovery \\
Predictive deconvolution \\
32-ms gap \\
200-ms operator \\
3 design windows \\
Time varying filter \\
Water bottom $\quad 3-5-50-60 \mathrm{~Hz}$ \\
End of record $\quad 3-5-30-40 \mathrm{~Hz}$ \\
Discrete velocity analyses \\
Normal moveout \\
Stack \\
f-k migration \\
Water bottom mute \\
Depth conversion
\end{tabular}


A

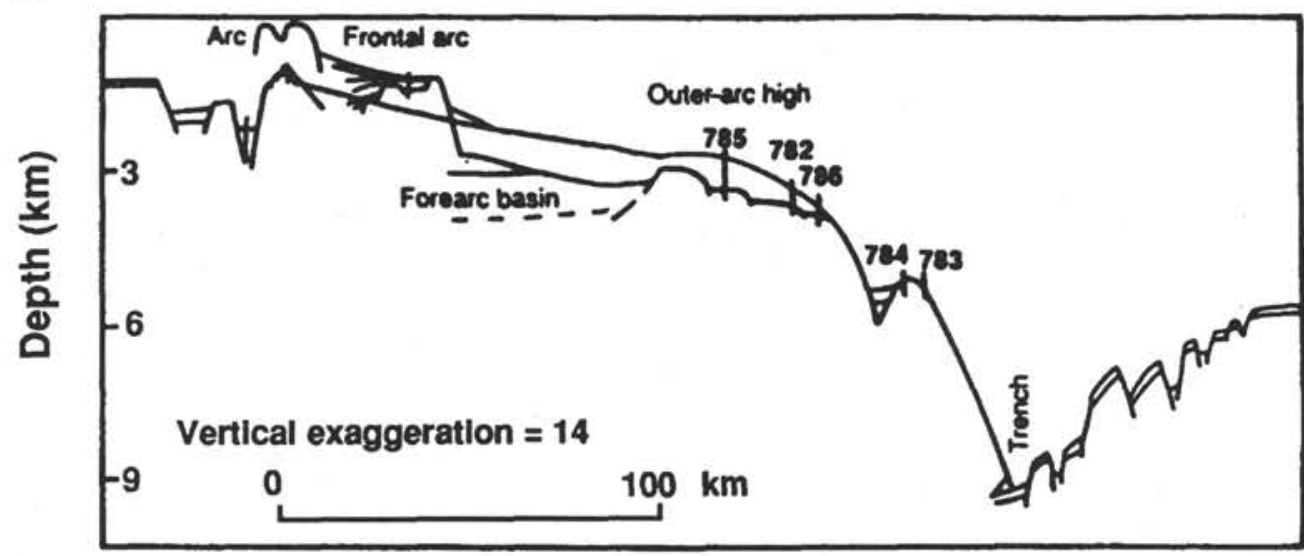

B

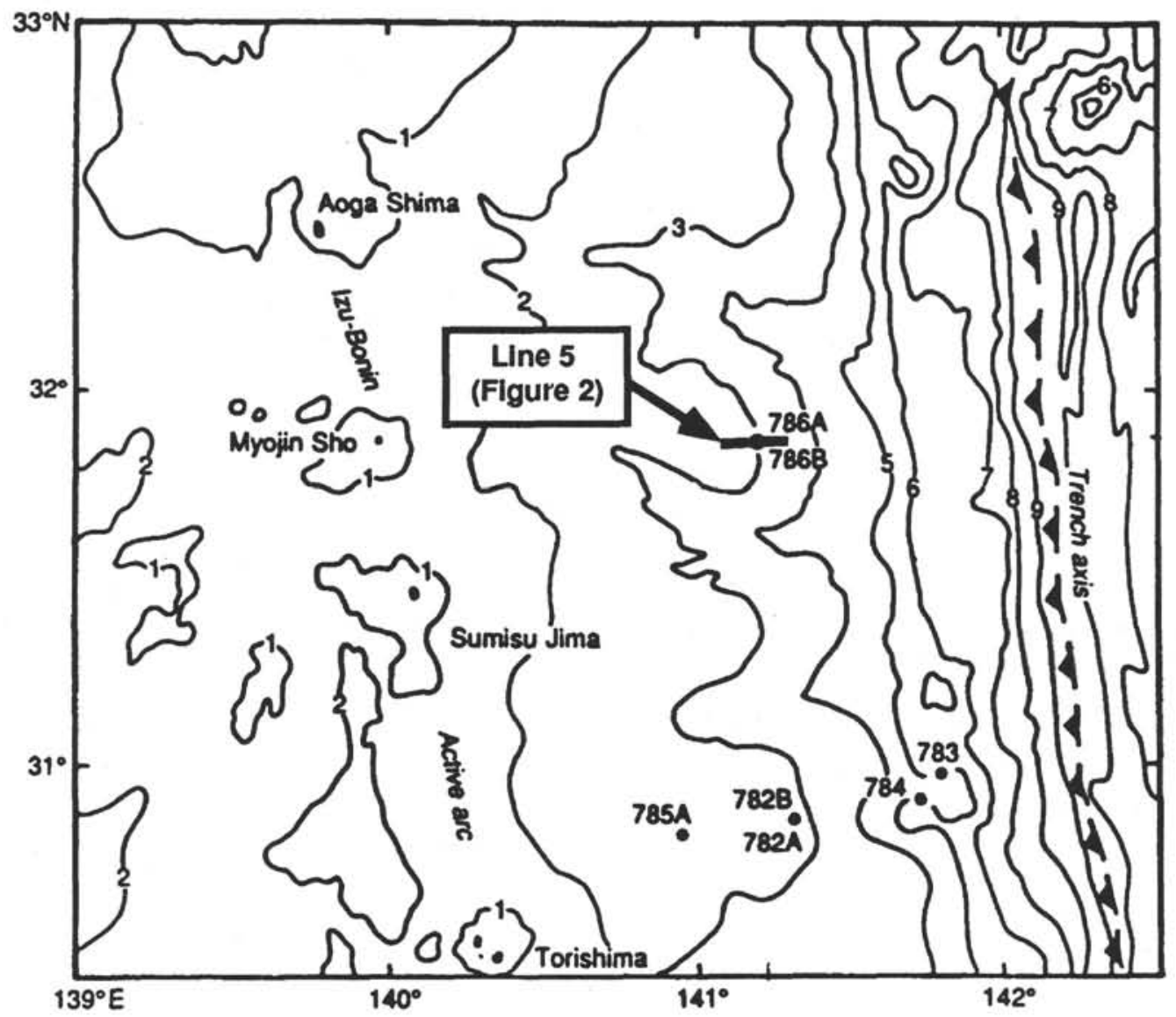

Figure 1. ODP Sites 782 through 786 in the Izu-Bonin forearc, as seen in schematic cross section (A) and plan view (B), and location of MCS Line 5 shown in Figure 2. Bathymetry in kilometers. Adapted from Fryer, Pearce, Stokking, et al. (1990).

ment are very short and discontinuous and commonly extend over only a few traces. Most reflections correspond to lithologic boundaries observed within the hole (Fig. 4). However, some reflections do not correspond to observed boundaries, but poor core recovery may indicate that some boundaries were missed during drilling. Variations in the reflections from igneous basement are to be expected because the diverse lithologic units recovered at Site 786 include massive brecciated flows, ash flows, and intercalated sediment in the upper section, as well as pillow lavas and dikes or sills in the lower section
(Fig. 4; Fryer, Pearce, Stokking, et al., 1990). Other diverse features discovered in the volcanic basement include conspicuous shear zones and hydrothermal breccias, which may add to the complex reflection geometry observed in the seismic reflection data.

\section{ACKNOWLEDGMENTS}

We thank Michael A. Fisher, Richard Jarrard, and R. H. Wilkens for their thoughtful reviews and comments. 


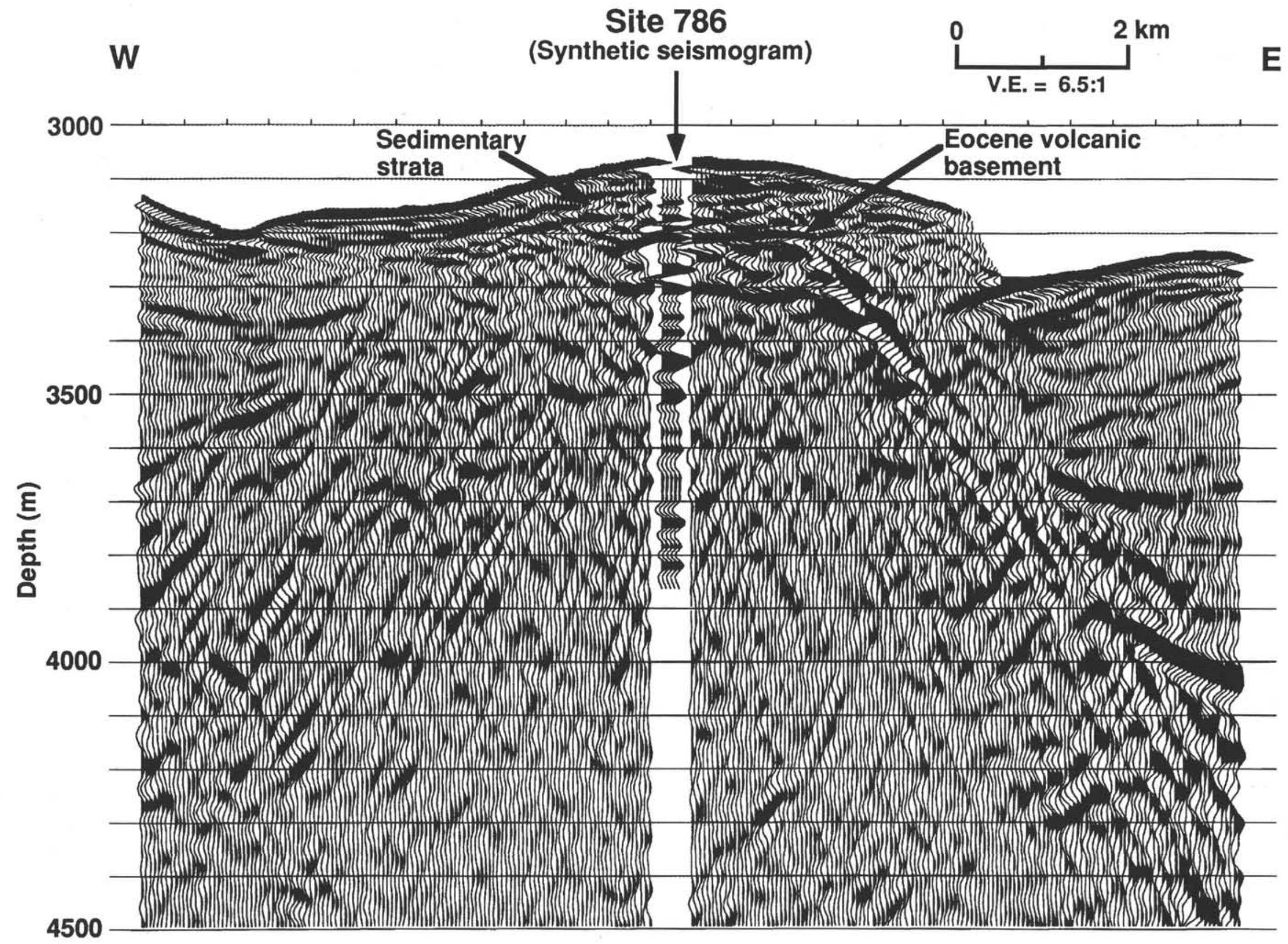



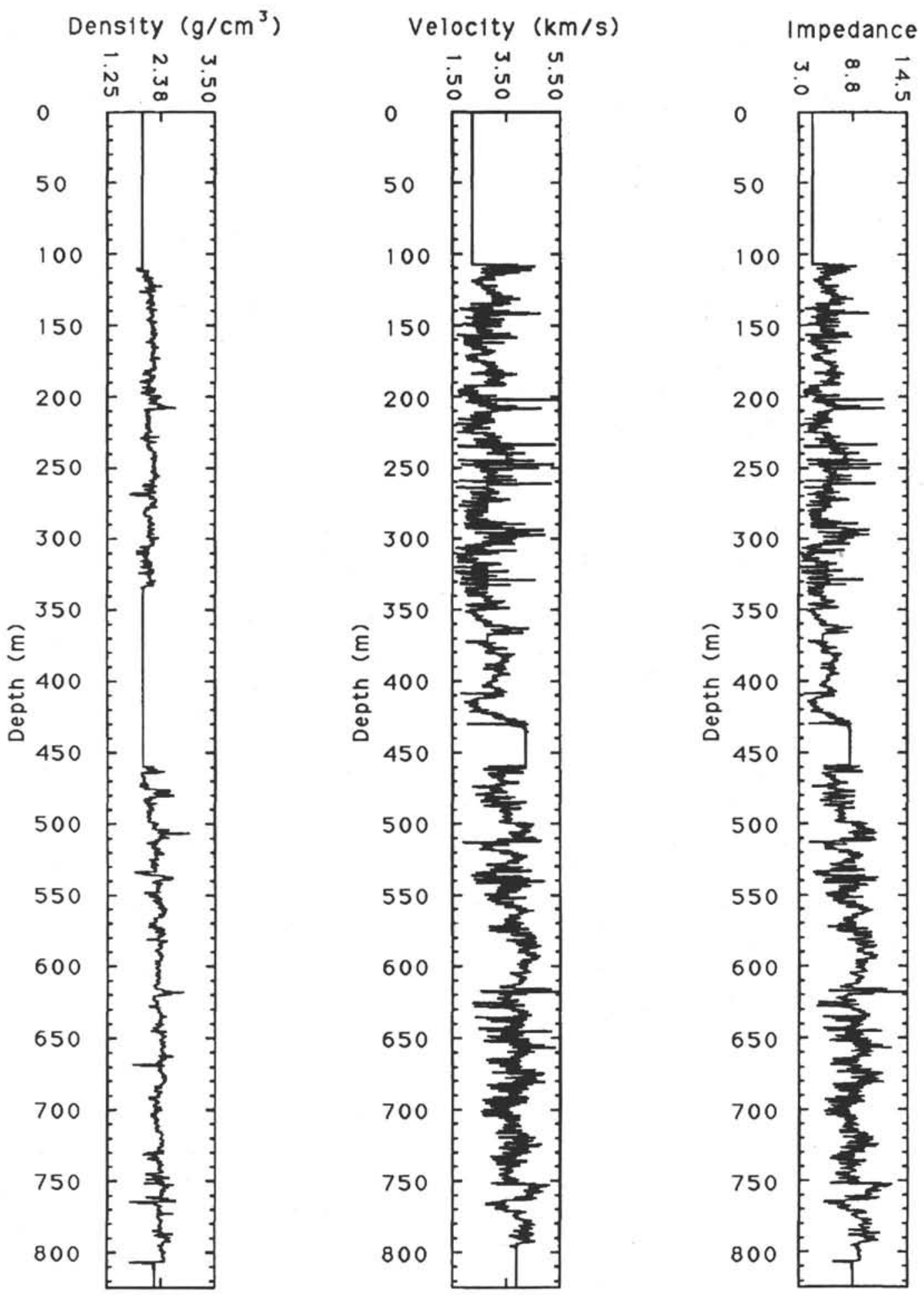

Figure 3. Logging data from Hole 786B, including density and velocity measurements, which were multiplied to produce the impedance data.

\section{REFERENCES}

Fryer, P., Pearce, J. A., Stokking, L. B., et al., 1990. Proc. ODP, Init. Repts., 125: College Station, TX (Ocean Drilling Program).

Horine, R. L., Moore, G. F., and Taylor, B., 1990. Structure of the outer Izu-Bonin forearc from seismic-reflection profiling and gravity modeling.
In Fryer, P., Pearce, J. A., Stokking, L. B., et al., Proc. ODP, Init. Repts., 125: College Station, TX (Ocean Drilling Program), 81-94.

Date of initial receipt: 26 September 1990

Date of acceptance: 18 March 1991

Ms 125B-182 
Synthetic seismogram

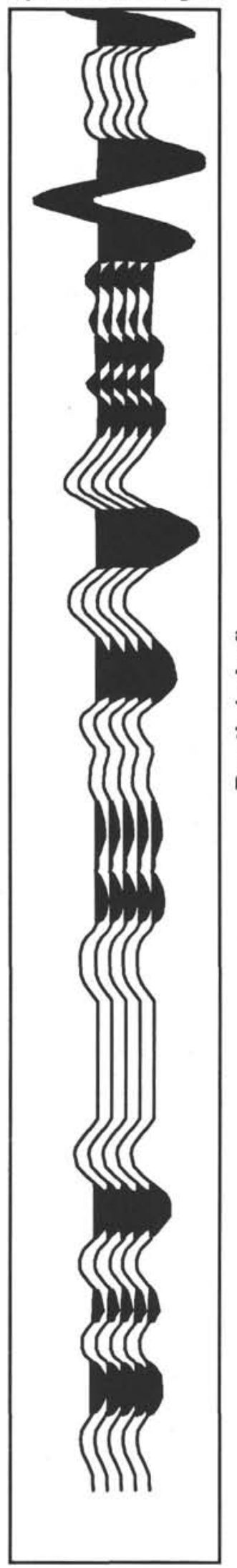

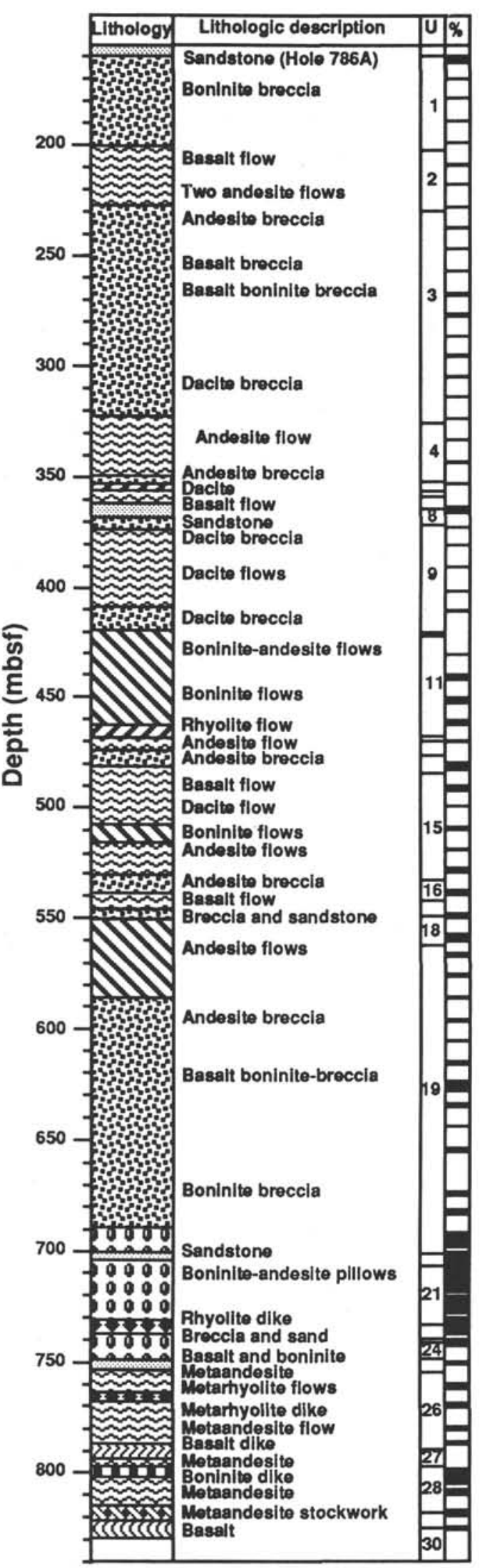

$\mathbf{U}=$ Lithology unit
$\%=$ Core recovery

Hole 786B

$($ Sea Floor $=3071 \mathrm{~m})$

\section{Explanation}

o. Pillows and hyaloclastite

Ereccia

$\approx$ Andesitic or basaltic flows

IJ Andesitic or basaltic dikes

Boninitic flows

Rhyolitic flows

Boninitic dikes

Rhyolitic dikes

Stockwork

$\square$ Sand, sandstone

Figure 4. Lithologic column from Hole 786B plotted against the synthetic seismogram shown in Figure 2. The top of the synthetic seismogram corresponds to a depth of $3200 \mathrm{~m}$ shown on Figure 2. 